\title{
Az információs társadalomért tevékenykedő civil szervezetek társadalmi beágyazódása és megítélése a fejlesztésekben érdekelt csoportok szemszögéből
}

Az INFONIA Alapítvány 2005 tavaszán összetett kutatási programot indított a magyarországi civil szervezetek körében. A tanulmány ennek a kutatás-sorozatnak a fókuszcsoportos beszélgetések formájában lebonyolított részét ismerteti és értékeli. A beszélgetések a magyar információs társadalom fejlettségéről és főbb problémáiról szóltak, s feltárták a meghívott kulcsszereplők nézeteit arra vonatkozóan, hogy Magyarországon kik tehetnek a legtöbbet az előbbre jutásért ezen a téren, és a civil szervezetek milyen szerepet játszhatnak a folyamatokban. A kutatás legfontosabb megállapítása, hogy az egyes szektorokban azonosítható „szereplővilágok” közötti kötőanyagot éppen azok a civil aktorok, legfőképpen a „félig civilek” adhatják, akiknek átjárásuk van a szereplővilágok között, mivel egyidejűleg többszörös identitásuk van.

\section{Szerzői információ:}

Juhász Lilla

Jogász, az ELTE Állam- és Jogtudományi Karán végzett 2003-ban. Jelenleg a Budapesti Múszaki Egyetem Információ- és Tudásmenedzsment Tanszékén egyetemi tanársegéd, a tanszék keretében múködô ITOK titkára és az Információs Társadalom és Trendkutató Központ kutatója. Az Európai Unió szakmai múhelyének tagja. Az ELTE-ÁJK politológiai doktori iskolájának hallgatója.

Pintér Róbert

Szociológus-politológus, 1998 óta a Budapesti Műszaki Egyetemen múködó Információs Társadalom- és Trendkutató Központ munkatársa, 2001 óta az Információ- és Tudásmenedzsment Tanszék tanársegédje. Számos hazai és nemzetközi kutatási program résztvevője. 2005-ben fejezte be tanulmányait az ELTE szociológiai doktori iskoláján. Ez év nyarától az Információs Társadalom címú folyóirat fốszerkesztôje. Kutatási területei: az információs társadalom elmélete; Magyarország és az Európai Unió információs társadalmi fejlettsége és politikája; új média; internetkultúra, internetpolitika, internetgazdaság; észak-európai információs társadalmak; elektronikus demokrácia.

\section{Így hivatkozzon erre a cikkre:}

Juhász Lilla, Pintér Róbert. „Az információs társadalomért tevékenykedő civil szervezetek társadalmi beágyazódása és megítélése a fejlesztésekben érdekelt csoportok szemszögéből”.

Információs Társadalom V, 4. szám (2005): 50-71.

L

https://dx.doi.org/10.22503/inftars.V.2005.4.4

A folyóiratban közölt müvek

a Creative Commons Nevezd meg! - Ne add el! - Így add tovább! 4.0

Nemzetközi Licenc feltételeinek megfelelöen használhatók. 
Juhász Lilla - Pintér Róbert

\section{Az információs társadalomért tevékenykedố civil szervezetek társadalmi beágyazódása és megítélése a fejlesztésekben érdekelt csoportok szemszögéból}

\section{A kutatás háttere és módszerei}

Az INFONIA Alapítvány 2005 tavaszán összetett kutatást végzett a magyarországi civil szervezetek körében „Civil szervezetek az információs társadalomban és az információs társadalomért - átfogó társadalomtudományi kutatás" címmel. A Nemzeti Civil Alapprogram (NCA) támogatásával folytatott kutatás a következố részekból épült fel:

- kérdőíves kutatás a hazai civil szervezetek részvételével azok informatikai felkészültségének felderítésére, ${ }^{1}$

- a civil szervezetek internetes jelenlétének vizsgálata (honlapok tartalomelemzése),

- interjúfelvételek az információs társadalom fejlesztésében érdekelt civil szervezetek képviselôivel, valamint sajtóelemzés a szervezetek tevékenységéról és a velük kapcsolatos diskurzusokról,

- fókuszcsoportos beszélgetések a kiemelt állami/politikai, gazdasági, akadémiai és civil szereplók részvételével a civilek szerepéról az információs társadalom fejlesztésében.

Ebben a tanulmányban a fókuszcsoportos beszélgetések módszerével végzett vizsgálat eredményeiról számolunk be. A beszélgetésekre 2005 áprilisában került sor a Budapesti Múszaki Egyetem Információ- és Tudásmenedzsment Tanszékén, összesen négy alkalommal, az ilyen jellegú kutatások számára speciálisan kialakított helyiségben. A beszélgetéseket a beszámoló készítói szervezték és vezették le. A beszélgetésekról mind a négy esetben hangfelvétel készült, a résztvevók beleegyezésével. Az alábbi elemzés a hangfelvételek alapján készült ún. „teljes nyers kiírás” szövegén alapul: ez az elhangzottaknak az élóbeszédet visszaadó, szerkesztetlen írásos dokumentuma. A tanulmányban szereplő idézetek szó szerint a résztvevoók által elmondottakból származnak, ezért - a beszélt nyelvhez hasonlóan - helyenként töredékes, kusza vagy befejezetlen mondatokat és különféle „kiszólásokat” is tartalmaznak.

\footnotetext{
${ }^{1}$ A részvizsgálatok anyagából készült tanulmányok közül kettô a Civil Szemle hasábjain, kettő az Információs Társadalom címú szakfolyóiratban, az összegezố tanulmány pedig a Kutatási Jelentés címú kiadványban lát napvilágot. Az NCA-hoz eljuttatott kutatási beszámolók teljes terjedelmükben olvashatók az interneten is: http://www.ittk.hu/web/kutatasok.html.
} 
A négy fókuszcsoportos beszélgetés (a továbbiakban röviden „fókusz”) résztvevôi a következố négy szereplő́csoport - az ún. „IKT elit” - tagjai voltak: ${ }^{2}$

- Kormányzati/állami szektor

- Gazdasági szektor

- Akadémiai-kutatói szféra

- Civil szféra

A beszélgetések idôtartama hetvenöt perc és százöt perc között volt, az érdemi részt megelôzó ismerkedéssel és a kutatási háttér, valamint a módszer rövid bemutatásával együtt. A kutatás átgondoltsága és a gondos szervezés ellenére is felmerült azonban néhány olyan módszertani probléma, amelyek részben hatással voltak a kapott eredményekre, ezeket elöljáróban jelezzük:

- A szakértókkel folytatott beszélgetések sikerét nagyban befolyásolja a résztvevớk száma. Ellentétben a hagyományos fókuszcsoportos interjúkkal, ahol hét-nyolc résztvevő tekinthetố az ideális létszámnak, a szakértókkel zajló beszélgetések szerencsés esetben négy-öt fő részvételével folynak. A szervezést azonban megnehezíti, hogy az átlagosnál sokkal elfoglaltabb személyekról van szó, akik akár a legutolsó pillanatban is lemondhatják a megjelenést, tehát célszerú az ideális létszámnál több résztvevớt meghívni. Másrészt viszont nem szabad egyetlen szakértốt sem hazaküldeni, ha egyszer hajlandó volt ránk szánni néhány órát, tehát ha mindenki megérkezik, akkor több résztvevốvel folyik a beszélgetés. A négy-öt főss csoportlétszám - amellett, hogy biztosítja a megfelelő csoportdinamikát lehetốvé teszi, hogy mindenki megfelelő mértékben szóhoz jusson, és egyrészt senkinek se maradjon fontos mondanivalója a beszélgetés végére, másrészt egyetlen résztvevő se kerüljön túlságosan domináns pozícióba a beszélgetés során. Ezt az optimális létszámot sajnos csak egyetlen alkalommal sikerült biztosítanunk (a kormányzati szektort 5 fő képviselte). A gazdasági szereplók képviselối jóval többen voltak (8fó), ${ }^{3}$ az akadémiai és a civil szférából pedig kevesebben vettek részt a beszélgetésekben (3-3 fố). ${ }^{4}$

${ }^{2}$ A négy csoport kiválasztásának elméleti indokolását a következő fejezetben írjuk le részletesebben. A beszélgetések résztvevóinek jegyzékét a melléklet tartalmazza.

${ }^{3}$ Ennek az okát abban a tényben véljük felfedezni, hogy a fókuszra meghívottakkal elốzetesen közöltük, hogy kik vesznek részt a beszélgetésen. A nagy cégek vezető beosztású munkatársai - látván, hogy mások már elígérkeztek - feltehetốen nem akartak távol maradni: ez a piaci versengés hatásának tulajdonítható. Ugyanakkor, ellentétben a többi fókusszal, amelyekre szintén nyolc-kilenc fốt hívtunk meg, itt szinte mindenki meg is érkezett, ami a gazdasági élet „business-like” múködésmódjának tudható be: ha az általunk megkeresett vezetố beosztású személy delegált valakit, akkor a beosztottja már nehezen tehette volna meg, hogy nem jön el.

${ }^{4}$ A három fôs létszámot tekinthetjük a minimumnak, ami mellett még biztosítható a fókusz dinamikája. Ezért fordulhatott elő, hogy a „civil” fókuszra jelentôs késéssel érkezó egyik résztvevốt - az ilyenkor szokásos eljárástól eltérve - befogadtuk a résztvevôk közé (a késôn jövók csatlakozását általában nem szerencsés megengedni, mivel vagy feljogosítva érzik magukat, hogy a távollétükben már megbeszélt témákhoz is hozzászóljanak, vagy nem tudják felvenni a fonalat: mindkét esetben tönkretehetik az egész beszélgetést).

Egyébként jellemzốnek is tekinthetô, hogy melyik beszélgetés hány fố részvételével és az eredetileg kitúzött idốponthoz képest mekkora késéssel kezdôdött el. A legkevesebben a „civil fókuszon” jelentek meg: a többé-kevésbé pontosan érkezett két fốhöz jelentốs késéssel csatlakozott egy további résztvevő, s így csak több mint félórás késéssel kezdhettük meg a beszélgetést. (A teljes képhez hozzátartozik, hogy ugyanezen a napon zajlott le az „Internet-hajó” rendezvénye, és a hajó kései kikötése miatt az egyik résztvevő egy- 
- Nehezítette továbbá a fókuszok szervezését az is, hogy sok szereplő nem volt egyértelmúen besorolható a négy szféra valamelyikébe. Különösen a civil szektor képviselôinél tapasztaltuk ezt. A kutatás egyik fontos tanulsága, hogy a „civileket” nem lehet olyan élesen elkülöníteni a többi szereplốtól, mivel a másik három szektor bármelyik tagjának is lehet (és gyakorta van is) valamilyen szervezetben „civil identitása”. Ezért többen akár másik csoportba is kerülhettek volna, mint ahová végül meghívtuk óket. ${ }^{5}$

- Az objektivitást bizonyos mértékig veszélyeztette, hogy a beszélgetést levezetô kutató, mivel már évek óta az adott témában tevékenykedett, személyesen is ismerte a résztvevốk jelentôs hányadát. Ez a helyzet azonban az efféle vizsgálatoknál nehezen kerülhetô el. Egyes vélemények szerint a szakértôi fókuszcsoportos beszélgetések nem csupán a résztvevốk hozzáértése miatt alkalmasak fontos jelenségek feltárására, hanem ehhez szükség van a beszélgetést vezetô kutató szakmai felkészültségére is az adott témában: nem egyszerúen csak a beszélgetés levezetési technikáiban kell járatosnak lennie, hanem magában a témában is, hogy a résztvevốk elfogadják a vezetését. Ezért döntöttünk úgy, hogy a fókuszt vezetố személy maga is a téma szakértôje legyen, még akkor is, ha ismeri a résztvevók egy részét.

- Végül a „civilek” esetében még az is nehezítette a fókusz lebonyolítását, hogy nagyon nehéz volt olyan résztvevớt találni, akit a korábbi részvizsgálat során ${ }^{6}$ nem interjúvoltunk meg (végül egy ilyen szakértốt sikerült bevonnunk). Ám az „ismerôs” szereplók is csak eleinte vélhették úgy, hogy pontosan tudják, mire irányul a kutatás, mivel a tematika -a közös kiindulópont dacára - csak részben volt átfedésben a korábbiakkal. Az interjúktól eltérốen itt nem a civil szervezetek belső világára, hanem a külvilággal való kapcsolataikra és a kulcsszereplốk viszonyaira koncentráltunk.

Végül röviden szót kell ejtenünk a fókuszok tartalmi szerkezetéról. A négy beszélgetés minden esetben a következố részekre tagolódott: ${ }^{7}$

- I. Az információs társadalom fogalma, fejlettsége és fóbb problémái Magyarországon.

- II. Szereplóvilág: azoknak az aktoroknak az azonosítása, akik Magyarországon a legtöbbet tehetnek az elörejutásért.

- III. Az azonosított szereplók között fennálló viszonyok.

- IV. A civil szervezetek és az a szerep, amit ténylegesen betöltenek a folyamatokban.

általán nem tudott megjelenni, pedig biztosra ígérte a részvételét. A résztvevốk számát csökkentette továbbá az is, hogy több olyan szereplốt, akik a „civilek” közé is kerülhettek volna, bizonyos megfontolások miatt egy másik csoportba soroltunk be - ennek indokolására késóbb visszatérünk.)

${ }^{5}$ Ilyen esetekben azt mérlegeltük, hogy az aktuális vizsgálat és a feltenni kívánt kérdések tekintetében a meghívottnak feltehetốen melyik identitása kerül elốtérbe. A NIOK képviselôjét például azért soroltuk a civil fókusz helyett az akadémiai csoportba, mert nem sokkal korábban részt vett egy viszonylag átfogó kutatás elkészítésében a „civil informatika” témakörében, ami jelentốs mértékben átfedésben volt a mi kérdőíves részvizsgálatunkkal. Más szereplók besorolása is hosszas mérlegelést igényelt, mivel az egyes szereplók meghatározhatják a beszélgetés irányát: ha egy valójában civil identitással rendelkezố szereplốt beültetünk egy másik csoportba, akkor vagy nem fogja jól érezni magát, és a háttérben marad, vagy olyan „bennfentes” civil témákat is felvet, amelyek az adott csoport képviselôi számára ismeretlenek, s ezért az utóbbiak esetleg laikusnak érezhetik magukat, és nehezebben nyilatkoznak meg más kérdésekben is.

${ }^{6}$ A mélyinterjús kutatás alkalmából.

${ }^{7}$ A beszélgetések részletes vezérfonalát mellékelten csatoljuk. 
Annak érdekében, hogy a beszélgetések tartalmát és tanulságait minél pontosabban tudjuk visszaadni, a továbbiakban - a rövid elméleti bevezetést követốen - beszámolónk is ezt a szerkezetet követi.

\section{Elméleti háttér: a "Wilson-gyémánt" működés közben}

A kutatás elméleti kiindulópontjául Ernest Wilson úgynevezett „gyémánt”-modelljét választottuk. Wilson az információ korába most vagy még ezután belépô fejlódő országok felzárkózását kutatva kettốs (egyidejúleg strukturalista és individualista - az emberi tényezókre orientált) megközelítési módot dolgozott ki a folyamatok megértéséhez (Wilson 2003, 2004). Elmélete szerint valamely technológia alkalmazása nem csupán egy eszközrendszer felhasználását jelenti, hanem egyszersmind egy viselkedésrendszer integráns része is a társadalomban, vagyis a tágabb társadalmi kontextusba való beágyazódottsága nélkül nem vizsgálható. Az egyszerú - és közkeletû - mutatók összehasonlítgatása éppen ezért sohasem adhat teljes képet, mert figyelmen kívül hagyja az egyedi kontextusokat. A gazdasági teljesítmény - rendszerint az egy före eső GDP értékével kifejezve - természetesen erős magyarázó értékú független változó lehet (Wilson szerint a technológiai diffúzió mutatói 60 százalékban erre vezethetók vissza), de jelentôs különbségek mutatkoznak a GDP/foó tekintetében közel azonos szinten álló országok között is. Az általunk is vizsgált területen (az IK'T-eszközök társadalmi használatbavétele terén) egyes országok az átlagosnál jobb, mások viszont rosszabb teljesítményt produkálnak. Wilson éppen arra a kérdésre kereste a választ, hogy milyen okok húzódhatnak meg e teljesítménykülönbségek mögött.

Wilson számos országban személyesen is végzett vizsgálatokat. Többek között Brazíliában, Kínában, Ghánában és Szenegálban folytatott terepkutatást, hogy a különbségeket ne csupán közvetett forrásokra támaszkodva elemezhesse, hanem kiváltó okaikkal együtt közvetlenül mérhesse fel, különbözố kontinenseken és különböző kultúrákban. Modelljében azonban az így tapasztaltak révén egyre inkább gyengülni látszottak a struktúrából fakadó meghatározottságok, és egyéb, korábban nem vizsgált változók tûntek fel. Ez utóbbiak között különösen fontosnak bizonyultak a személyes felelốsség körébe utalható hatások. Wilson - miután megismerkedett a helyi szakemberekkel és a kulcspozícióban lévố döntéshozókkal - a korábban általa felállított strukturalista megközelítésú modell helyett az emberi tényezóknek sokkal nagyobb szerepet biztosító, kevésbé merev modellt kezdett el kidolgozni, amelyben a struktúra mellett döntô szerepet játszanak az egyének közötti kapcsolatok is.

Így jutott el a technológiai indíttatású társadalmi modernizáció sajátos modelljéhez, amelyben a fố szektorok szereplói között aktuálisan fennálló dinamikus viszonyra helyeződik a hangsúly. Wilson tézise szerint minden modernizáció sikere az állam, a magánszektor, a civil sźéra és az akadémiai šféra (a tudományos kutatások világa) közötti kapcsolatok minôségétól függ. A vizsgált országokban a modernizáció kezdetén mindig az állam volt túlsúlyban (különösen igaz ez a deklaráltan szocialista rendszerekre). A fejlődés menete pedig szorosan összefügg azzal, hogy az állam mennyit és hogyan képes ebból a központi szerepéból, az általa gyakorolt hatalomból és ellenőrzésból átengedni más szereplóknek. A kulcskérdés mindig az, hogy azok az aktorok, akiknek ez a „hata- 
lomátadás" sérti a személyes érdekeit (mert kevesebb lesz a befolyásuk, vagy rosszabb lesz a gazdasági pozíciójuk stb.), mennyire vannak középponti helyzetben, például képesek-e elgáncsolni vagy lefékezni a fejlődési folyamatokat.

Az átmenet kezdetén elôször a zárt monopolista struktúrát kell lebontani. Ehhez azonban jó belsố viszonyokra, a szereplók közötti bizalomra és a különbözố szektorok közötti átjárásra, hatékony kommunikációra van szükség. E nélkül nincs sikeres modernizáció. Részben ez magyarázza, hogy közel azonos gazdasági teljesítményú országokban miért lehet eltérố a fejlődés üteme, illetve aktuális szintje. Van, ahol az átjárás és a bizalom megvan a szereplók között, máshol pedig hiányzik vagy igen alacsony szintú.

Wilson szerint - a fenti megfontolások alapján - a modernizációs átmenet szakaszai a fejlődő országokban a következók:

1. piac elótti: az állam hatalmas, a többi szereplố nem releváns, fóleg a civil szféra kicsiny és fejletlen;

2. piacosodó: az állam ereje csökken, a magánszektor felduzzad, a civil szféra erốsödik, szerepet kap a tudomány is;

3. versengó: az állam szerepe egyre kisebb, a piaci szereplók versengenek, a civil szféra tovább erôsödik, az akadémiai szféra szerepe kibóvül;

4. negyedik szakasz: az állam hatáskörei alacsonyabb szinten stabilizálódnak, a piac konszolidálódik, a civil szféra jelentôsége megnő, a tudomány világa egyenrangú partnerré válik.

A négy szereplő között fokozatosan minden irányban nyitott kommunikációs háló jön létre, amit Wilson „négyes” vagy „gyémánt”-struktúrának nevezett el (röviden: Quad). Az átmenet akkor sikeres, ha ez a gyémánt ki tud alakulni, vagyis a szereplók között minden irányban hatékony kommunikáció jön létre.

Tulajdonképpen minden szakaszban változik a (hatalmi) struktúra, de ez nem jelenti azt, hogy ezzel a társadalmi egyenlótlenségek és a belsố konfliktusok is maradéktalanul megoldódnának. Wilson tézise szerint minden legújabb kori modernizáció sikere a fóbb szereplök (az állam, a magánszektor, a civil szféra és a kutatói-egyetemi világ) közötti kapcsolatrendszer müködésétól függ, vagyis ez a négyes olyan szerkezetet alkot, amelyben meghatározó jelentôségúek a szereplók között meglévő kommunikációs és intézményes kapcsolatok, a bizalom szintje és a kölcsönösség mértéke. Minél teljesebb a struktúra (minél hatékonyabban funkcionálnak a kommunikációs csatornák), annál jobban múködik az átmenet vezérlése.

Magyarországon a rendszerváltás óta eltelt évek folyamán az „információs kapitalizmus" egyfajta kelet-közép-európai változata alakult ki, sajátos helyi jellegzetességekkel, ami a Wilson-gyémánt négy fóbb szereplője közötti viszonyrendszer tekintetében az alábbi vonásokkal határozható meg: az állam kezdeti túlsúlya, a gazdaság és a (multinacionális) tóke megerósödése, a lakosságnak az átalakulási folyamatokkal kapcsolatban egyidejüleg megnyilvánuló bizalmatlansága és lelkesedése, a civil társadalom lassú erösödése, az akadémiai szféra marginalizált helyzete, és végül a négy szereplő közötti kommunikáció nehézkessége, akadozása.

Mindez azonban Magyarországra vonatkoztatva csupán elméleti megállapítás. Bár Wilson modellje az elmúlt években ismertté és meglehetôsen népszerúvé vált itthon (fóleg a társadalomtudományi kutatók körében, de közvetítésükkel bizonyos mértékig más szférákban is), empirikus vizsgálatára mindeddig nem került sor. Voltaképpen nem 
tudhattuk, hogy egyrészt a négy szféra képviselói hogyan látják ezt a fejlódési folyamatot, és maguk az érintettek vajon igazolják-e az elmélet érvényességét (ók is úgy gondolják-e, hogy valóban az említett szereplók - és a köztük meglévő kapcsolatok - a leginkább meghatározó jelentôségúek a folyamatokban, vagy pedig más tényezóket esetleg fontosabbnak tartanak stb.).

Éppen ezért a kutatás során lebonyolított fókuszcsoportos beszélgetések nem csupán a civil szektorra, illetve annak az információs társadalomért tevékenykedố részére koncentráltak (ez a komplex kutatási programon belül a mélyinterjús és a sajtóelemzési vizsgálatok feladata volt), hanem kiléptek a Wilson-gyémántnak ebból a csúcsából és a civil szféra kapcsolatrendszerét, beágyazódását és környezetét tették vizsgálat tárgyává, vagyis lényegében az egész hazai „IKT-elitról” készítettek egyfajta látleletet - azzal a céllal, hogy ezen belül jobban megismerjük a „civil szegmens” helyzetét és sajátos jellemzóit.

A „fókuszok" során elốfordult, hogy a résztvevók egyes civil szervezeteket - azok státusát hibásan percipiálva - valamelyik másik szektorhoz soroltak (például a Teleház Szövetségról a gazdasági fókusz résztvevối azt gondolták, hogy állami szervezet). ${ }^{8}$ A civil szereplók körében ad absurdum még önmaguk számára is a saját jelentéktelenségük az egyik legfontosabb identitáselem: a civil fókusz résztvevói gyakorlatilag nem tudtak olyan civil szervezetet megnevezni, amely kifejezetten az információs társadalomért tevékenykedne - miközben a mélyinterjús részvizsgálat során mi magunk több mint harminc ilyen NGO-t azonosítottunk. ${ }^{9}$

\section{Az információs társadalom fogalma, fejlettsége és főbb problémái Magyarországon}

A beszélgetések megkezdésekor ${ }^{10}$ elôször mindig azt a „színpadot” próbáltuk azonosítani, ahol a szereplók ,játszanak”, ahol az interakciók végbemennek közöttük. Egymás után körbejártuk tehát az alábbi kérdéseket:

- Az információs társadalom fogalma

- Magyarország fejlettsége

- Hazai problémák

- A civilek helyzete ebben a közegben

Az információs társadalom fogalmát illetốen sajátos kettôsség volt megfigyelhetô minden fókusz során: a résztvevók a beszélgetés kezdetén elvontabb megközelítéssel, mintegy társadalmi rendszerként kezelték a fogalmat, összetett jelenségvilágként utal-

${ }^{8}$ "- Teleház-mozgalmat mondom, amit nem mondtatok eddig, mert még senkinek nem jutott eszébe, de eszébe is juthatott volna akár.

- Azt miért nevezzük civilnek?

- Azt miért nem a kormányzathoz sorolod?"

${ }^{9}$ Erre a mélyinterjúk és sajtóelemzés módszerével végzett vizsgálat folyamán került sor.

${ }^{10}$ A beszélgetés elsố blokkja a módszernek megfelelóen általában valamilyen tágabb kérdéskörból indul ki, amelybố a késóbbiekben fókuszálni lehet a szúken vett témára, esetünkben a civilek szervezetek szerepére az információs társadalomban. 
va rá. A beszélgetés előrehaladtával azonban ez akaratlanul is zárójelbe került, elfelejtốdött, és a konkrétan felmerülő problémák tárgyalásakor a fogalom aktuális tartalmaként rendszerint már az internethasználat, az információs és kommunikációs technológiák, a digitális szakadék stb. jelent meg. Az „információs társadalom” kiépitése tehát a résztvevók tudatában - és szakmai diskurzusában - gyakorlatilag a infokommunikációs eszközök társadalmi elterjedését és széles körü felhasználását jelenti.

Az elvont fogalom értelmezéseként elhangzott, hogy az információs társadalom „a termékek és szolgáltatások immaterializálódása, digitális alapokra helyezése, mivel az információs társadalomban a társadalom új alapokra épül”. Az akadémiai fókuszon felmerült néhány társadalomtudományi megközelítés is:

- Makroszinten: „A munkaerő hány százaléka dolgozik az információs társadalomban?”

- Mikroszinten: "Mérhetố, idốmérlegekkel vizsgálható, hogy megtörtént-e, illetve milyen mértékû az információs társadalom kiépülése - például mennyi idốt töltenek az emberek a médiával, belemerülnek-e a kibertérbe?"

Magyarország fejlettségének témája természetesen szorosan összefügg a következő blokkal, vagyis azzal, hogy a hazai folyamatokban melyek a legfontosabb problémák. Kérdés persze - amint az fel is merült -, hogy mihez mérjük az információs társadalom fejlettségét, vagyis mihez képest értékeljük Magyarország fejlettségét vagy fejletlenségét. Ahogy fentebb utaltunk rá, itt már múködésbe lépett az információs társadalom leegyszerüsített fogalma, tehát internetpenetrációról, eszközhasználatról, az interneten elérhetố tartalmakról, szolgáltatásokról stb. esett szó, a résztvevoók ezeken a mutatókon keresztül mérték a hazai fejlettségi szintet.

Mindezek alapján néhány általános megállapítás tehetô Magyarország fejlettségére vonatkozóan. Általában elmondható, hogy a fókuszokon hangoztatott vélemények szerint az információs társadalom kiépítése terén az ország lemaradásban van:

„[...] korábban bizarr hangæású országokról, mint Szlovákia meg Románia, büsะkén mondtuk, hogy haha, a Keleti blokkon belïl, hogy le vannak tóliük maradva... Nincsenek. Söt. Masszivan elôttünk vannak. Sikerült addig tökölni, amíg ezek a korábban esélytelennek tünö országok simán beelóatek. A következố Horvátország lesz."11

Elhangzott, hogy Magyarországon az információs társadalom - az elvárásokkal ellentétben - „bizonyos szegmensekben gyorsabbá tette az életet, de hatékonyabbá nem”. Ez felveti az idóháztartás problémáját: az információs társadalom kialakulása gyorsabbá teszi a folyamatokat, de minden tevékenység mögött valós idóigény áll, és ez egyre több aktív, „múk ödtetni muszáj” kapcsolatot feltételez. A probléma nemcsak az egyén szintjén, hanem a nagyobb rendszerek szintjén is felmerül, például a civil szféra és az állam viszonyrendszerében, ahol szintén nincs egyszerüsödés (lásd: pályáztatás).

Ami az információs társadalom hazai problémáit illeti, a legtöbben itt tudtak először bekapcsolódni a beszélgetésbe, erre ugyanis szinte mindenki tudott példákat mondani.

\footnotetext{
${ }^{11}$ A dólt betúvel szedett idézetek - külön jelölés nélkül - minden esetben a fókuszokon elhangzott megnyilatkozásokból származnak.
} 
Miután minden alkalommal pillanatok alatt az infokommunikációs eszközök elterjedése és társadalmi használatbavétele került a középpontba, a problémák kapcsán is erre koncentráltak a résztvevoók. A felvetések a következő csoportokba sorolhatók:

- Hozzáférési problémák: Feltételek, eszközök hiánya, az új alkalmazások megismerésének és birtokbavételének nehézségei, sürgetố szükség a felhasználók képzésére és a lehetôségek megismertetésére.

- Digitális egyenlötlenségek (szoros összefüggésben az elôzố ponttal): Az eszközök (elsősorban az internet) elérhetốsége és avatott használata egyaránt problematikus. Idetartozó területek: képzettség, internetpenetráció, az egyes településtípusok és régiók közti különbségek, gender-szakadék.

- Érdektelenség, közöny, negatív attitúdök: Elhangzott olyan vélemény, miszerint „az internet legnagyobb problémája az, hogy számítógépen keresztül érhetố el, amit sokan elutasítanak”. Gyakran említették az igények hiányát is. „Az információs társadalom fejletlensége generációs probléma - az elszigeteltség az információs társadalom kiépítésének gátja. Pedig személyes példák alapján elmondható, hogy az idősek is bevonhatók."

- Nem megfelelötartalom és szolgáltatások: A tartalom elóállításánál túl erôs az üzleti jelleg, és a közigazgatásnak is többet kellene tennie a megfelelő́ színvonalú elektronikus szolgáltatásokért.

- Elégtelen koordináció: Hiányzik az információ koordinálása, összehangolása - az állami igazgatás ellenérdekeltsége érvényesül, pedig fontos lenne, hogy egyáltalán gazdája és megfelelő gazdája legyen a területnek. Ebbe beletartozik, hogy legyen stratégia, de négyévente ne legyen teljes irányváltás a területen. Bár az elmúlt években olyan kedvezố programok is elindultak, mint amilyen a Teleház vagy a Sulinet, ezek a példaadó kezdeményezések „nem érnek össze”.

Bár a vezérfonal szerint a civilek az első blokkban még nem szerepeltek önállóan, tehát rájuk vonatkozóan nem hangzott el konkrét kérdés, többen - a meghívás alapján ismerve a beszélgetés fớ témáját - mégis úgy érezték, hogy már a problémák felvetésekor sem általánosságban, hanem konkrétan a civilekre vonatkozóan kell megfogalmazniuk a mondanivalójukat. Így elhangzott néhány megállapítás kifejezetten a civil szervezetek helyzetével kapcsolatban is:

- A civil szervezetek anyagi szempontból nem nyertek az internet bevezetéséból, ugyanakkor az internetnek köszönhetôen egyre több feladatot látnak el.

- A civil tartalom soha nem lesz üzleti jellegú, miközben nyilván versenyeznie kell más tartalmakkal a figyelemért.

- Az internetes hozzáférés hiánya csökken a civilek körében, miközben a KSH 2003. évi jelentése szerint a civilek 30\%-ának nem kell az internet.

- Azoknak a civil szervezeteknek az aránya, amelyek saját honlappal rendelkeznek, 20\% alatt van. Az internet az elit civil szervezetek médiuma. Sok esetben a civilek számára csak addig érdekes a honlap, amíg nekik maguknak nincs saját portáljuk; gyakorta fel sem ismerik, hogy mire tudnák használni a világhálót.

- A NIOK felmérése szerint (Török-Oprics, 2004) sok szervezetnek még irodája sincs, ami sok esetben kizárja, hogy saját információs és kommunikációs infrastruktúrával rendelkezzen.

- A civileknél hiányzik a hálózatszervezés és az önszervezôdés. 
Mindent összevetve kijelenthetố tehát, hogy mind a négy fókusz esetében az információs társadalom fogalmának igen gyakorlatias értelmezése mentén indult meg a gondolkodás, és az elhangzottak alapján Magyarországról megállapítható, hogy jelentôs lemaradásba került még a környezó országokhoz képest is.

\section{Szereplővilág: A főszereplők és a közöttük lévő viszonyok}

\section{Szereplôk a kulcsszereplókról - hierarchialisták}

A következő kérdés - az elôző blokk legfontosabb megállapításához kapcsolódva, miszerint Magyarország egyre inkább lemarad - az volt, hogy kik tehetnek valamit ez ellen, vagyis kiknek van lehetôségük beleszólni a fejlesztési folyamatokba, kik azok a kulcsszereplók a magyar információs társadalmi térben, akik a legtöbbet tehetnek az elốbbre jutásért. ${ }^{12}$

Bár a kérdés egyszerúnek tủnik, mind a négy csoportban komoly gondokat okozott az értelmezése, majd a megválaszolása is. A résztvevók az explicit kérdésfeltevés ellenére sem tudták elkülöníteni egymástól a sein és a sollen világát, vagyis a „hogyan múködik itt és most” kérdésébe folyamatosan belekeveredett a „hogyan kellene múködnie általában” kérdése és egy „normális” társadalomban illúziója. Következésképpen a „mi nem egy normális országban élünk”, a „bezzeg Nyugaton” modalitás mindaddig uralta ennek a kérdésnek a megvitatását, amíg egyértelmúen, többször is el nem hangzott, hogy most nem ez a diskurzus tárgya, hanem annak a végiggondolása, hogy 2005-ben Magyarországon kik számítanak a legfontosabb szereplóknek, akik az elôzőekben felvázolt problémavilág kezelése terén a legtöbb hatalommal, befolyással és cselekvési lehetôséggel rendelkeznek.

Az egyes fókuszokon részt vevố szakértók a következố szereplóket azonosították kulcsszereplóként a hazai információs társadalomban (a sorszámok az aktorok hierarchiájára is utalnak, a résztvevốk által percipiált erôviszonyoknak megfelelően):

Az egyes szektorok képviselóinek percepciója a magyar információs társadalom kulcsszereplôiról:
A) Kormányzati szektor
1. Üzleti szektor: bankok, kereskedelem, pénzügy
2. Közpolitika (hatalom)
3. Média
4. Közszolgáltatást nyújtó intézmények - közigazgatás
5. Oktatási intézmények
6. Civil szervezetek - decentralizált szervezetek
7. Háztartások, lakosság

\footnotetext{
${ }^{12}$ Elôször csak azonosítottuk ezeket a szereplóket, és az említések sorrendjében felírtuk ôket a helyiségben lévố táblára. Ezt követốn kezdtünk el „dolgozni” velük - ezzel a következố fejezetben foglalkozunk részletesebben.
} 


\section{B) Gazdasági szektor}

- „Mínusz 1.” Kormányzat, önkormányzat, stratégiaalkotás, minisztériumok (Miniszterelnöki Hivatal, Elektronikus Kormányzati Központ, az Országgyúlés Informatikai Bizottsága $)^{13}$

- „Plusz 1.” Üzleti szektor: Multik, kis- és középvállalkozások, mikrovállalkozások. Tartalomszolgáltatók, az IKT eszközök gyártói. ${ }^{14}$

- 3. Oktatás és képzés

- 4. Elektronikus és nyomtatott média

- 5. Civil szervezetek

- 6. Tudományos szféra

C) Akadémiai szektor

1. Állam: politikai akarat, közigazgatás, minisztériumi apparátusok, önkormányzatok, pártok

2. Üzleti szektor: vas, drót, internetárak, online szolgáltatások általában, szoftver szabványok. Közvetett és közvetlen szereplók.

3. Felhasználók, tömegoktatás

4. Jogvédók, fogyasztóvédók, lobbisták, civilek (hiánya), IT-érdekvédók

5. Nemzetközi szereplók: források, oktatás, globális civil társadalom

D) Civil swektor

1-2. Gazdaság

1-2. Politika: az éppen hatalmon lévố politikai pártok

3. Állam és közigazgatás: a politikai akarat végrehajtása

4. Média

5-6. Tudományos szféra, kutatók

5-6. Civil szervezetek

\section{A wilsoni kategóriák percepciója}

Ha megnézzük a fenti négy felsorolást, talán meglepetésként érhet minket, hogy több-kevesebb változtatással, de mind a négy esetben maguk a szereplók is a wilsoni négyeshez hasonló szereplőgárdát állítottak össze. Akad viszont néhány igen fontos eltérés is. Előfordul például, hogy a wilsoni négyes egyes szereplối elő sem kerülnek, miközben a résztvevốk öt-hét szereplốt mindenhol nevesítenek ${ }^{15}$ (a kormányzati szektorból az akadémiai szektort nem is „látják”, és az akadémiai szektorból - sokatmondó jelzésként - szintén ez maradt ki, vagyis a szektor képviselői önmagukat nem sorolják a főszereplók közé, míg mindhárom másik csoport „öntudatosabb”). Ugyanakkor vannak

\footnotetext{
${ }^{13}$ A mínusz jel minôsítést fejez ki: azt jelzi, hogy ez a szektor a legfontosabb szereplő, de erôsen deficites a múködése.

${ }^{14}$ A szembenállás jele arra utal, hogy az üzleti szektoron belül versengés folyik és konfliktusok vannak.

15 Tehát a kimaradás fó oka nem egyszerúen az, hogy a megnevezett szereplók számossága kicsi, hanem az, hogy a csoportban részt vevók számára nem tartoznak a legfontosabb szereplók közé a wilsoni négyes egyes tagjai.
} 
olyan szereplók, akik mindössze egy-két helyen szerepelnek, és nem mindenütt kerülnek elő önállóan (például lakosság, oktatási intézmények, nemzetközi szereplók). A két legérdekesebb, több csoportban is tapasztalt jelenség azonban minden kétséget kizáróan a kormányzati szféra kettéválasztása politikára (hatalomra) és közigazgatásra (végrehajtó apparátusra) - ez a kormányzati és a civil fókuszban hangzott el - és a média mint önálló szereplö megjelenése - ezt az akadémiai szektor kivételével mindegyik fókuszcsoport felvetette.

$\mathrm{Az}$ állam kettéválasztását politikára és közigazgatásra elsốsorban a magyar közélet átpolitizáltsága indokolja, ami azt is maga után vonja, hogy a szakapparátus minden választás után kicserélődik. Másrészt az a helyzet, hogy míg a nagypolitika számára az információs társadalom kérdése a gyakorlatban nem élvez elsôrendû prioritást, addig a közigazgatásban jól azonosíthatóan léteznek a téma iránt elkötelezett szereplốk (pl. IHM), és fontos fejlesztési programok futnak. Ezt a kettôsséget felismerve a két alszektort el kell különíteni egymástól, ami a wilsoni modellben nem lehetséges, ezért az ebben a vonatkozásban nem is képes megmagyarázni a magyar sajátosságokat:

„A kormányt és a közigazgatást ne keverjük, mert akkor másról beszélïnk. [...] Én azt mondom, hogy abban a szituációban, amikor a politika olyan cserélödési hatást okoz a közigazgatásban minden egyes választás után, mint ma lejátszódik, abban a szituációban elég erớs ráhatás van, [...] nem kéne így lennie, mert gondolom, hogy egy államtitkár vagy államtitkár helyettesi szinten meg kellene est állitani, de most egyelöre még nem ez történik. [...] Különösen akkor, amikor olyan civil szereplö, mint én megnézem ast, hogy kivel vagyok kapcsolatban egy adott szakminisztériumban, és akkor utána nem gyózök az arcokhoz alkalmazkodni, mert négy éoben körïlbelïl háromszor cserélik az osztályt."

„A közszférában tényleg elkülönül két érdek. Az egyik az a közszolgálat vagy közigazgatás, a másik a politika. És az nem ugyanaw a csúcs. Mert hogy aะ kettévált."

„Nyilvánvaló, hogy a közpolitikának, a hatalomnak is van egy szerepe ebben az egész információs társadalom kérdésében. Az, hogy a politika mit túz a zászlajára."

A média mint önálló szereplő fontossága az akadémiai fókusz kivételével mindegyik fókuszcsoport tagjai számára gyakorlatilag megkérdójelezhetetlen volt. Az elhangzott vélemények szerint a média kétségtelenül kulcsszerepet játszik a tudatosság növelésében, a vélemények formálásában és a tájékoztatásban, de többnyire igen negatív színben jelenik meg. Különösen azt róják fel hibájául, hogy eltakarja a valóságot és hamis színben tünteti fel a folyamatok középpontjában lévố internetet:

„Az a probléma, hogy a média mit közvetít. [Ö] azt hiszi, hogy transzparens, és közben abszolút nem a\%. Tehát az, amit a média közvetít, az emberek azt hiszik az a valóság, és közben pedig nem aะ a valóság. [...] Lehetséges, hogy nem abban a szerepben kéne lennie, mint amiben pillanatnyilag gyakorlatilag van, de ott van, és az:al számolni kell."

„Az internet úgy jelenik meg számára [a hétköznapi ember sáamára - P.R.], hogy lehet onnan letölteni bomba receptet, meztelen nốt, gyerek pornót és pedofil lapot. Ez jelenik meg az internet kapcsán egy egyszerü embernek a médiában." 
A média ebból a szempontból hasonlít tehát az államhoz: miközben nagy felelősség terheli és igen sok feladatot ellát, tevékenységének megítélése inkább negatív: még többet kellene tennie és jobban kellene múködnie, mint ahogyan jelenleg múködik.

A beszélgetéseket követố napokban elgondolkodtunk azon is, hogy vajon vannak-e olyan nagy társadalmi szereplók, amelyek elméletileg meghatározóak lehetnek, de mind a négy felsorolásból kimaradtak. Egyetlen ilyet sikerült azonosítani, mégpedig az egyházat - hacsak nem tekintjük úgy, hogy azt a szereplók kimondatlanul is a civil szervezetek közé sorolták. Az egyház hiánya azonban könnyen magyarázható azzal, hogy a mai magyar társadalom egyrészt nem különösebben vallásos, másrészt pedig az egyház mint intézmény - többnyire konzervatív jellegénél fogva - eleve kevés országban és kevés esetben tölt be meghatározó szerepet az információs társadalom kiépítését célzó modernizációban (az olyan országok kivételével, ahol a vallás erôsen áthatja az egész társadalmat, s ennek köszönhetốen sikerrel hallathatja a hangját). ${ }^{16}$

\section{A szereplők közötti viszonyok}

Természetesen nemcsak az érdekes, hogy melyik szereplóket tartják fontosnak az egyes szektorok képviselói, hanem az is, hogy mennyire tartják fontosnak óket, illetve milyen viszonyrendszert tételeznek fel közöttük. A fentebb leírt sorrendek a hierarchia mellett a belsố tagozódásra és helyenként a belsố-külsố konfliktusokra is rámutattak.

A beszélgetésnek ebben a részében alapvetôen arra a kérdésre kerestük a választ, hogy az említett szereplók között milyen viszonyok állnak fenn: Ki dominál, kik az elsôdleges, meghatározó szereplók?

A dominancia és a hierarchia tekintetében elmondható, hogy mind a négy esetben a: egymással szoros kapcsolatban lévó gazdaság és az állam keriilt a lista élére. Két esetben (a gazdasági és a civil fókuszban) még csak erôsorrendet sem sikerült felállítani közöttük, egyenrangú félként azonos sorszámot kaptak. Ez a két szereplő a másik két szektor (az akadémiai és a civil szféra) képviselói szerint valósággal „rátelepszik” a fejlesztési programokra, és a lehetốségek, a hatalmi potenciál tekintetében az összes többi aktor nagyságrendileg lemarad mögöttük:

„Ha arra gondolsz, hogy a gazdasági elit mit bír elérni politikai szinten, hogy az ó érdeke érvényesïljön, tehát ilyen szempontból hajlok [arra - P. R.], hogy majdnem lehet, hogy fontosabb [mint az állam]. [...] nem tudok ilyen vagy-vagyokban gondolkodni, mert úgy éræem, hogy majdnem egyforma [az állam és a gazdaság - P. R.]. Nincsen alá-fölé rendeltség."

„Tudok egy konkrét példát, [...] as esélyegyen löségi törvényböl totál kimaradt a vállalkozói vagy az üzleti szféra. Nem vonatkozik rá az esélyegyenlöségi törvény, és ezt a civilek nem birtuk elérni, hogy bekeriiljön, hiába volt az állam részéról vagy a közigazgatás részéról [ támogatás -P. R.J, nem vonatkozik rá az esélyegyenlóségi törvény. Csak a közigazgatásra vonatkozik, és ez

${ }^{16}$ Az egyház háttérbe szorulása Magyarországon leginkább akkor válik érthetővé, ha olyan országokra gondolunk, mint például Lengyelország vagy Olaszország, ahol a társadalmi kérdésekben, az emberek hétköznapjaiban és a kulturális közeg, az érvényes értékrendek meghatározásában az egyház sokkal fontosabb szerepet tölt be, mint a mai Magyarországon. 
tuti biztos, hogy ki is mondták, hogy ez egyszerüen a gazdasági szféra elérte a politikánál, hogy vegyék ki belöle ezt. Tehát érted, amikor ilyen szinten bele tud nyúlni a gazdasági szféra, hogy a tör vények például az öérdekei szerint születnek és lesz belóle egy csomó katyvasz, és nem tudom egyébként, mert ebben nem vagyok naprakész, hogy információs társadalomra mikor születnek esetleg olyan alkuk, amik pont lehet, hogy az információs társadalom fejlódését akadályozzák, ha tudnék erre most példát mondani, az jó lenne. Erre értettem, amikor azt mondtam, hogy lehet, hogy a gazdasági lobbi olyan erós, nyilván átszövi a politikát, mert ott vannak az emberei, de est az egyetlen egy éló példát tudom, mert általában est puffogtatják, hogy a gaะdasági lobbi érdekei, meg a politika stb."

A gazdasági és a kormányzati szereplók természetesen „különvéleményt” fogalmaztak meg ezzel kapcsolatban, amit az is jól jelez, hogy a gazdasági fókuszban az állami szektor „mínusz egyest” kapott a teljesítményére, vagyis azt elfogadják, hogy az állam a legfontosabb szereplő, de igencsak rossz hatásfokúnak tartják a múködését. A gazdasági élet képviselöinek saját szerepüket illetốen nincsenek illúzióik, tudják, hogy kulcspozícióban vannak, de egyrészt visszautasítják, hogy minden esetben keresztül tudják vinni az akaratukat az állammal szemben, másrészt elhárítják azt a felelôsséget is, amit a többi szereplő hozzájuk rendel: szerintük az információs társadalom építése elsôsorban az állam feladata, nem pedig a gazdaságé.

„Az üzleti sæféra biztos, hogy beszél a kormányzattal, legalábbis próbálkozik, és a kormányzat is idönként tesz olyan lépéseket, amellyel megpróbálják bevonni az üzleti szférát bizonyos döntésekbe. Erre lépések vannak, az más kérdés, hogy mennyire hatékony."

„Van egy érdekes szempont az üzleti szférán belïl. Az üzleti sঞféra alapvetóen profitorientált, a célja és a feladata az minden vállalkozásnak, hogy nemcsak, hogy megéljen, hanem jól tudja eltartani azokat, akik ebból élnek. Viszont ha ez a iizleti szféra vállalja föl adott esetben az információs társadalom népszerüsitését, akkor nemcsak a saját potenciáját növeli, hanem a saját konkurenciájáét is. Gondolok itt arra, hogy egy fényképezógép-gyártó, egy mobiltelefon-gyártó, egy mobilszolgáltató gyártó, ha növeli az érdeklódést a mobiltechnológiák iránt, akkor nem feltétlenül csak ahhoz az egy mobilszolgáltatóhoz fognak eljutni az emberek, hanem elmennek a konkurenciához is. Ez egy olyan hülye helyzet bizonyos értelemben, hogy mindenki szeretné növelni a tortának a nagyságát, de a torta nagyságával a szeletek nagysága is nó, amit a többiek kihasítanak, ami egy gyilkos verseny."

Ugyanez a felelősségelhárítás megfigyelhetô a kormányzati oldalon is. A kormányzati szektor képviselói többnyire a gazdaságra mutogatnak vissza, azt tekintve a legjobb helyzetben lévő szereplőnek, amely a legtöbbet teheti a fejlesztésekért és sokkal nagyobbak a lehetôségei, mint az államnak. Ezek szerint a közigazgatásban és a nagypolitikában prioritások versenyeznek egymással, és az információs társadalom (értsd: az internet, illetve az infokommunikációs eszközök elterjesztése) csak egy a sok terület közül, ahová pénzt kell tenni, ahol lobbiznak az erôsebb állami szerepvállalásért. 


\section{Ki micsoda a szereplők közül?}

A beszélgetések negyedik szakaszában érdekes ,játékot” ajánlottunk a csoportok résztvevóinek. Azt kértük tólük, hogy minden általuk azonosított szereplốról mondják meg az eddigiek alapján, hogy milyen élólény (növény vagy állat) képét idézi fel bennük. Egy ilyen játék nagyon hasznos, mivel képes felszínre hozni azokat az attitúdöket, elnyomott vélekedéseket és nehezen racionalizálható vagy megfogalmazható, érzelmi indíttatású beállítódásokat is, amelyek egyébként javarészt rejtve maradnának.

Hely hiányában itt csak a négy wilsoni kulcsszereplő egymásra vonatkoztatott „ki kicsoda?" percepcióját mutatjuk be, majd ezt követốen csak a civilekre vonatkozó jelzések értelmezésével foglalkozunk röviden:

A) Kormányzati szektor ${ }^{17}$

- Üzleti szféra és közpolitika együtt: összefonódott polip

- Állam: hiéna; hatóság: szamár

- Közpolitika: szúnyog, kaméleon

- Közigazgatás: sün

- Civil szektor: öszvér, vak $10^{18}$

B) Gazdasági szektor

- Kormányzat: mamut, lajhár, dinoszaurusz

- Üzleti szektor: vadászkutya, gepárd, tigris, ${ }^{19}$ fürge rókalábak, kopó (falkában), dögevő, hiéna, ragadozó

- Civilek: egysejtú, veréb, ${ }^{20}$ csótány, patkány ${ }^{21}$

- Tudományos szféra: elefánt, teknősbéka

C) Akadémiai szektor ${ }^{22}$

- Állam: plankton, döglött béka, „mega” medúza, kisgömböc

- Üzleti szektor: ravasz róka, óriás krokodil

- Fogyasztóvédók és „IT civilek”: árnyék, gyerek sólyom, ${ }^{23}$ okoskodó lajhár (a „Jégkorszak" címú rajzfilmból $)^{24}$

- Civilek: mókus ${ }^{25}$

${ }^{17}$ A kormányzati fókusz esetében a szereplốk felsorolása során hiányzott az akadémia, ezért ebben a „megnevezôsdiben” sem találkozunk velük.

${ }^{18}$ Indoklás nélkül hangzott el.

19 "Kicsit túldicsérjük magunkat."

${ }^{20}$ "Összeszedi, ami van, megél belóle, néha sokan vannak, és zavaróak, és el kell kergetni óket."

21 „Patkányt mondanék. Azért, mert nagyon életképes." (Ezzel többen nem értettek egyet, volt, aki elszégyellte magát, és nagy vita bontakozott ki.)

${ }^{22} \mathrm{Az}$ akadémiai szektor önmagát nem nevezte meg kulcsszereplóként, ezért az ő felsorolásukból hiányzik az önkép.

${ }^{23}$ "Gyerek sólyom. Nem vadászik ez még, pici, etetni kell, de majd egyszer megnó, és majd lecsap a nem tom mire."

${ }^{24}$ "Elvileg inkább hátra vitte a dolgokat, de túl sokat mondott ahhoz, hogy ne lehessen nem ésære venni. Néha csinált jót is, néha úgy jött be neki, hogy jó lett véguil."

${ }^{25}$ "Ugrándozik, rágogat, csinálja a dolgát." 
D) Civil szektor

- Politika: dzsungel, hínár, kaméleon, magyar futballista (!)

- Tudományos szféra: szomorúfúz, bagoly

- Gazdaság: cápa vagy tigris

- Állam: lajhár, orrszarvú, szarvasmarha

- Civilek: hangyaboly, ${ }^{26}$ szarka, ${ }^{27}$ kislány, ${ }^{28}$ koalamackó ${ }^{29}$

A három másik szereplốnek a civilekról kialakított képe valamilyen fajta elaprózottságot, szívósságot, akár már zavaró túlélési ösztönt feltételez, miközben részben arra is utal, hogy a civil szektor még további fejlődés, növekedés, kiteljesedés előtt áll. Ez több elemében egybecseng a civilek önképének lényeges elemeivel is (a kislány és a hangyaboly momentuma), vagyis hogy a civilekre jellemzố a nyüzsgés, a „sok kicsi sokra megy" ethosza, a szorgos tevékenykedés, és ugyanakkor lehetôség van a növekedésre. Mindeközben azonban egyfajta keserúség jeleként ott van a naivitásra való utalás, valamint az is, hogy bár a felszínen mindenki szereti óket, valójában azt szeretik, ha mutogathatják óket, miközben csendben bódítják magukat és nem sok vizet zavarnak (koala). Végül a sæarka magyarázat szerint itt azt jelezheti, hogy a civilek sokszor szembekerülnek másokkal, és emiatt kudarcot vallanak.

Érdekes a civileknek a többi szereplőról alkotott képe is. A politikából való teljes kiábrándulást a magyar futballista hasonlata ragadja meg a leginkább. Az állam - a megszokott módon - lomhaságával, tunyaságával túnik ki. Az akadémiai kép ikonikus jellege miatt meglehetôsen közhelyszerú (,Egy olyan szomorúfúz, amin ül egy bagoly.”). A gazdaságnál a ragadozó természet emelkedik ki, de bizonyos korlátozásokkal („A gazdaságnál a cápa és a tigris között gondolkodtam, de lehet, hogy túl erós [...] és a magyar gazdaság nem annyira."). Fontos, hogy itt - a gazdaság és a civil szféra kettôsénél - található a legnagyobb aszimmetria: a gazdasági szereplốk szinte egyetlen pozitív tulajdonságot láttak a civilekben, a sokszor túlzásba vitt élni akarásukat, miközben a civilek a föld legrettegettebb ragadozóihoz hasonlították óket.

\section{A civilek súlya és szerepe az információs társadalomban}

A civilek súlyának megállapításához először is tisztázni szükséges, hogy kiról is beszélünk. A „civilség” definíciója körül mind a négy fókuszcsoportban vita bontakozott ki arról, hogy egyáltalán kit tekinthetünk civilnek és kit nem. Ezt egyrészt azért volt különösen fontos tisztázni, hogy közelebb juthassunk annak a kérdésnek a megvá-

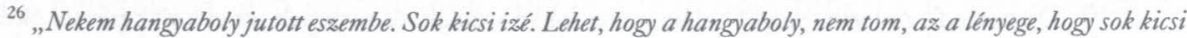
nyïzsög valamit."

27 „,-Kikérem magunknak!

- Sokat akar a szarka, de nem bírja a farka. A civil szervezetek, akik akarnak, de a többiekkel szemben, tehát nem azért nem bírja a farka, nem az igazi szarka hasonlat.

- Nekem ar jutott eswembe, aki lop."

${ }^{28}$ „Nekem a kislány jut eszembe a civil szervezetekre. Aranyos, jót akar, nincs nagy befolyása, kicsit naiv. De szép lány lesz belôle."

${ }^{29}$ "Mindenki szereti, ne csináljon semmit. Odateszik neki az eukaliptuszlevelet, de csak azs eszi, ami bódit."
} 
laszolásához, hogy milyen funkciókat láthatnak el a civilek a magyar információs társadalomban, másrészt pedig azért, hogy számba vehessük az információs társadalomért tevékenykedő hazai civil szférát, és el tudjuk határolni a nem civilektól.

A definícióról folytatott vita többnyire arra az eredményre vezetett, hogy a meghatározás lehet egészen szúk is, ami csak az önkéntes alapon szerveződő, gazdasági-politikai érdekeltséggel nem rendelkezố szervezeteket öleli fel, de általában a többféle módon, rugalmasan tágítható meghatározásokat részesítették elônyben. A fogalmi sokszínúséget a civil szektor megjelölés használata mellett a „,nonprofit szervezet”, a „nem kormányzati szervezet" (Non-Governmental Organizations, NGO) és a "társadalmi szervezet" elnevezések is tükrözik. A beszélgetések során a résztvevók megállapították, hogy léteznek olyan szervezetek, amelyek tulajdonképpen szektorköziek: ilyenek például a gazdasági érdekképviseletek, amelyek szúken véve nem tekinthetók civilnek, de társadalmi szervezetek, és tevékenységük miatt nem sorolhatók egyértelmúen a gazdasági szférához sem. Hasonló szektorközi helyzetben vannak az állam által létrehozott közhasznú társaságok is.

A civil szféra hazai beágyazódásának helyzetét és fellépésének potenciális sikertelenségét jelzi, hogy a fontossági sorrend tekintetében a résztvevók minden esetben az utolsó helyek valamelyikére tették: a kormányzati csoport számára csak a lakosságot előzi meg, a gazdasági csoportban egyedül a tudományos szféra van mögötte, az akadémiai csoportban megbontva a két utolsó kategóriát adja, és még a kategória megjelölésében is a hiányukat emelik ki, végül pedig még maguk a civilek is a fontossági sor legvégére teszik önmagukat (a tudományos szférával együtt). Ám nemcsak emiatt állítható, hogy a információs társadalom fejlesztésére irányuló programok és tevékenységek terén a civilek gyakorlatilag nem léteznek, láthatatlanok, a többi szereplössámára súlytalanok, és a hiányukkal tüntetnek. Ezt a képet erôsítik a beszélgetésekben részt vevók megnyilvánulásai is:

„Gyakorlatilag nincsenek jelen. Egyfolytában ezen gondolkodom, mióta erról beszélgetünk [hogy kik az ide sorolható civilek - P. R.], a netért jó, de és még?"

„Inkább az, hogy kik nincsenek. Tehát ilyen electronic frontiers foundation típusú jogvédó, internetes szabadságért kïzdó, kifejezetten információs jogokért küzdó. Tehát információs önrendelkezési szabadságért kïzdó, és az állami átláthatóságért küzdó szervezeteknek érzem én a legnagyobb hiányát. Majtényi-féle és Galántai-féle csoportok, és most két embert nevestem meg, és nem igazán szervezeteket. Nem nagyon vannak szervezetek."

„Szám szerint van pár, de tényleg nem nagyon. Nem ebben a témában, hanem... egyszer mentem véletlenül be megnézni, hogy milyen a: IHM-ben egy civil fórum, és ott igy ültek körben emberek. Ott iult a Gáspár Matyi, meg a Gáspár Matyi, meg a Gáspár Matyi."

Sajnos kijelenthetô, hogy kevés civil szervezet, és kevés olyan elkötelezett, a témában járatos és jól felkészült civil szakember van ma Magyarországon, aki partnere lehetne a más szektorokban múködő kulcsembereknek. A helyzet azonban mégsem annyira gyászos. Egyrészt megmagyarázható, hogy egyelóre miért nincs túl sok civil szervezet ezen a téren (ami azt vetíti előre, hogy ez a helyzet idóvel megváltozhat, ahogy azt a civilek várható növekedését kódoló hasonlatok (kislány, kis sólyom) is jelzik, másrészt számtalan esetben - mintegy a más szférákban végzett munkahelyi tevékenység „melléktermékeként” - tulajdonképpen civil vélemények jelennek meg, csak éppen nem civil szervezeti formában: 
„És akkor mi lehet az oka a hiányuknak?"

„Szerintem az, hogy ez egy nagyon tudásintenziv terület, ahol túlterheltek az emberek, pontosan azért mert ök, vagy mi vagyunk legjobban benne ebben a terïletben, és meg is fizetik a piackonform tudást, tehát elsæivják az agyakat a más sæereplók a civil terïletröl.

Valamit felvetnék, hogy lehet, hogy van civil jelenlét, de nem szervezetileg megfogható. Szabadszoftvertól kezdve az ITTK-klub listáig egy csomó olyan helyen látok egyéni strukturált, okos, nyomásgyakorló véleményeket, amit valószinúleg a munkahelyükön irnak as emberek, mert a forprofit szektorban vagy az államnál dolgownak, de a véleményük valahogy megjelenik. Tehát nem civil szervezeti keretekben jelennek meg civil vélemények."

Ugyanakkor nemcsak az agyelszívás, az emberek túlterheltsége és atomizáltsága lehet a civil szervezetek hiányának az oka, hanem - ahogy a gazdasági fókuszcsoportban fogalmaztak - a civilek megfoghatatlansága és gyökértelensége, valamint a kedvezôtlen politikai-gazdasági környezet is:

„Mert megfoghatatlanok. Nem olyan, mint a kormányzat, hogy ott az IHM épülete, egy jó nagy célpont és lehet rá ágyúval lóni. Nem is tudtuk definiálni óket aw elején, és astán elég gyorsan megállapitottuk, hogy a webes tartalmak nagy része tólïk van. Az internetes felhašnálók elég nagy része ugyancsak tólïk van."

„Én ellentétes véleményen vagyok. Én ast mondom ebben a dologban, hogy a civil szektor ebben a* információs társadalomban és a: interneten keresztül hihetetlen nagy erövel van ott, de nem artikulálódik. Tehát értem ezalatt, amit te mondtál, sokféle van, és ez különbözö kis igényeket relatíve a társadalom egészére [...] elégít ki, és ezek nem összegzódnek olyan szinten. Van mikor valami miatt összeállnak, és akkor megjelennek ezek a dolgok, de alapjában véve masszívan a civil szervezódések fölismerték a: internet és a hálózat hatását, és est használják, amennyire az ó anyagi és képességbeli dolgaik megvannak. [...] Beszéltünk arról, hogy 15 év alatt jöttek létre a civil szervezódések, ez nem egy életkor egy társadalmi fejlódésben és egy tókeszegény közegben, ahol ráadásul a civil érdekérvényesités nem is volt soha. A mostani pártrendszerben még inkább nincsen tere ennek a dolognak. Tehát kere-lába össze van kötve, és két és fél métert kéne ugrania ennek a civil szervezódésnek Magyarországon."

A felsorolt problémák ellenére - vagy éppen ezek miatt - számos olyan feladat van, amit a más szférákhoz tartozó résztvevók meglátásai szerint a civileknek kellene ellátniuk. Ilyen lehet a jogvédelem, az internetes szabadságjogokért való küzdelem, illetve a fogyasztóvédelem. A civil szektor sokat tehet a szektorok közötti közvetítésben is, hiszen a legtöbb civil nem fớálásban tevékenykedik civilként - ahogy azt a meghívottak többszörös identitása is mutatta. Sokan vannak, akik civil érdekeket képviselhetnek a munkahelyükön, és a munkahelyi világukat jeleníthetik meg a civilek között.

A fókuszok tanulsága szerint a civilek feladata, hogy minél több helyen megjelenitsék az információs társadalom értékeit, hogy az információs társadalom értékei és prioritásai legalább megfogalmazódjanak. A legsürgósebb feladat azonban a közremúködés annak a feltárásában, hogy a mai magyar információs társadalom továbbépítésében mi lehet a legfontosabb húzóerố. 


\section{Összegzés}

A kutatás - jellegénél fogva - nem egyszerúen csak a civilekre vonatkozóan bővelkedik tanulságokban, hanem az információs társadalom hazai fejlettségére általában, továbbá az érintett szereplókre, valamint a kiindulási alapnak tekintett wilsoni elméletre vonatkozóan is fontos újdonságokat tár fel.

A fókuszcsoportos beszélgetések elsô blokkjában nem derült ki egyértelmúen, hogy mit is nevezïnk információs társadalomnak. Miközben több beszélgetés kezdetén is utalás történt arra, hogy egy új, az ipari társadalmat felváltó paradigmáról van szó, a késóbbiek során ez mindig elsikkadt, és maradt az információs és kommunikációs technológiák társadalmi elterjedése, legfóképpen pedig az internet és a számítástechnika mint legfóbb attribútum vagy differentia specifica, amivel az „,információs társadalom” meghatározható.

A vizsgálat második blokkját nézve jól látható, hogy a szereplók tudatában nem kristályosodik ki a wilsoni négyes, bár kisebb-nagyobb eltérésekkel mégis ezt rekonstruálják a beszélgetés során. Többnyire belép a média mint fontos ötödik szereplő. A wilsoni állami szféra kettészakad érdekvezérelt nagypolitikára (hatalom) és közigazgatásra (végrehajtó apparátus), de előfordul, hogy még ennél is cizelláltabban (minisztériumokra, önkormányzatokra, hivatalokra stb. lebontva) jelenik meg. A gazdaságban elkülönülnek a nagy multinacionális vállalatok nemzeti szintú leképeződései és a helyi vállalkozások. Az akadémiai szféra mellett önállóan jelenik meg az oktatás mint tudatosságnöveló és (nép)neveló feladatot ellátó szereplő (Wilson az oktatást a tudományos szférához sorolja). Egyesek önálló kategóriaként említik a felhasználókat, a lakosságot is. Végül szinte mindig artikulálódik a regionalitás és a globalitás problémája, vagyis hogy mit kezdjünk az olyan, a nemzetnél kisebb vagy nagyobb képződményekkel, mint amilyen például az Európai Unió.

Míg az egyik oldalon kibóvül a wilsoni négyes, addig a másik oldalon, a kapcsolatrendszer és a belsô hierarchia bemutatásakor rögtön le is szúkül: az állam és a gazdaság uralja a „színpadot”, ennek a két szereplőnek a kezében vannak a döntések és a fejlesztési programok. A többiek egyrészt mellözöttnek érzik magukat, másrészt ezt valahogy természetesnek fogadják el, és éppen ettól a kettốstól, „felülról” várják a kezdeményezéseket és a „megváltást”.

Ezzel szorosan összefügg, hogy mivel a szereplók szinte kivétel nélkül felülról jövő - a politikától, illetve a gazdaságtól kiinduló - megoldásokat keresnek, gondolkodásmódjuk egyfajta felïlról lefelé haladó logikát követ. Ez pedig olyan kulturális közeget hoz létre, ami egyáltalán nem kedvez a civil megoldások genezisének és beágyazódásának. A civilek múködését is az átpolitizált, gazdasági indíttatású rend igazgatja.

Jellemzô, hogy a „hogyan múködik (itt és most)” kérdését mindegyik csoport összekeverte a „hogyan kellene múködnie (általában)” kérdéssel. Ez arra mutat, hogy a témáról való gondolkodást bújtatottan áthatja $a$ ö̈nsorsrontás nemzeti önképe („mi nem egy normális országban élünk”, „mi képtelenek vagyunk”, „lehetne ezt jól is csinálni”, „bezzeg Nyugaton”).

Jellemző továbbá a hazai helyzetre, hogy eközben szinte mindegyik csoport képviselói másokra (és külsö tényezókre) hárították a felelósséget a saját szerepuik betöltésében mutatkozó deficitekért, ami helyenként tetten érhetô azokban a hasonlatokban is, amelyeket egymásra aggattak. 
Kutatásunk szúken vett tárgyára, a civil szférára vonatkozóan a vizsgálat egyik legfontosabb tanulsága az, hogy igencsak problematikus, kit is nevezhetiink civilnek. Tovább rontja a helyzetet az a természetes okokkal magyarázható jelenség, hogy ritka a csupán civil identitással rendelkezố civil, továbbá egyes kívülról nézve idesorolható szereplók gyakran maguk sem tekintik magukat civilnek. Ezért fontos értelmezési kérdés, hogy kit is tekinthetünk civilnek, úgy, hogy indokolatlanul ne zárjunk ki senkit sem ebból a körból, de ne is tágítsuk ki túlságosan a kereteket. Ha a civilek csoportját szúkebb értelemben határozzuk meg, vagyis nem értjük bele az érdekképviseleteket (például IVSZ), az ernyốszervezeteket és az akcelerátorokat (pl. NIOK, Zöld Pók) vagy a nemzetközi „fiókszervezeteket" (például magyar W3C), és csak az alulról jövơ kezdeményezésként létrejött, minden közvetlen gazdasági és politikai érdektól mentes és tisztán hazai civil szervezôdéseket soroljuk ide, akkor valóban nagyon kevés olyan szervezetról adhatunk számot, ami az információs társadalom kiépítésének jegyében fejti ki tevékenységét.

Különösen azért fontos ez, mert a ,félig civilek”, például az állam által létrehozott közhasznú társaságok, a gazdasági szereplốk érdekképviseletét ellátó különféle társadalmi szervezetek, a nemzetközi szervezetek helyi csoportjai stb. fontos közvetító szerepet látnak el az egyes szereplók között - nem a wilsoni gyémánt valamelyik csúcsán, hanem a köztük lévő közvetítô tengelyen „ülnek”.

A legfontosabb szereplók meghatározásából leszúrhetố további fontos tanulság, hogy a wilsoni elmélet esetleg módosításra szorulhat: legalábbis Magyarországra adaptálva (és feltehetôleg számos más ország esetében is) feltétlenül megfontolandónak látszik a média „,beemelése” a kulcsszereplók közé. Ugyanakkor - az elmélet érvényességét igazolva - a fókuszcsoportos beszélgetésekból is kiderült, hogy a fejlődést és az adott intézményrendszer aktuális múködését, hatékonyságát és outputjait elsôsorban a szereplók közötti viszonyrendszer határozza meg, ahogy azt Wilson is állítja. Ebból a szempontból a fókuszcsoportos kutatás legfontosabb felismerése az, hogy a szereplóvilágok közötti kötöanyagot éppen azok a civilek, legföképpen a ,félig civilek" adhatják, akiknek átjárásuk van az egyes szektorok között, mivel egyidejüleg többszörös identitással rendelkeznek. A probléma csupán az, hogy ezek a „félig civilek” - például a nagy befolyással rendelkezố gazdasági érdekképviseletek - egyáltalán nem tartják magukat civileknek, aminek az az egyik legfontosabb oka, hogy a gazdasági szektorban a civil szférának meglehetősen rossz a megítélése (lásd patkány, veréb). A civil szféra „szegény rokonnak” számít, az idetartozók hatalma a legkisebb, s ezért senki sem akar önként a civilek közé számítódni, sorsközösséget vállalni velük. Persze ez kölcsönös, a civilek sem tekintik a civil köntösbe öltözó különféle állami és gazdasági szereplóket ,igazi civileknek”, mivel ezek tulajdonképpen csak másfajta eszközzel próbálnak érvényt szerezni saját érdekeiknek. Így válnak kicsit gyanússá egymás számára a „félig civilek” és az „,igazi civilek”, ami megnehezíti köztük a kommunikációt, és így a közvetítő funkciót is gátolja. Ez pedig végsố soron a hazai információs társadalom fejlődésének is a kárára van.

Ebból következik néhány fontos további tanulság is:

- megfigyelhetô a civilek tüntetô „,hiánya”: a civil funkciókat többnyire vagy mások látják el, vagy senki sem látja el óket;

- meghatározó a civilek láthatatlansága: sok esetben sem más szereplók, sem maguk a „civilek" nem tartják egyértelmúen civilnek még azt a kevés létezó szereplót sem, aki van; 
- végül mindez kumulálódik a civilek mellôzöttségében és gyengeségében: a szereplók hierarchialistáin rendre az utolsó helyre szorulnak, ami jól mutatja lehetôségeiket az érdekérvényesítésben.

Az vigasztalhat bennünket, hogy ez a kutatás csak egy pillanatképet vázol fel, ami a 2005 tavaszi állapotokat rögzíti. A civil szektor - a társadalom egészével együtt - folyamatos mozgásban és fejlődésben van, tehát minden bizonnyal eljöhet még az az idő, amikor Magyarországon is felnô az információs társadalom kiépítése terén rá váró feladatokhoz is.

\section{Irodalom}

Török Marianna - Oprics Judit (2004): Magyarországi civil szervezetek informatikai és egyéb kommunikációs jellemzói. BME-ITTK Kutatási Jelentés, 27-28.

Wilson, III, Ernest J. (2003): The Information Revolution in Developing Countries. Cambridge, MA: MIT Press.

Wilson, III, Ernest J. (2004): Scholarship and Practice in the Transitions to a Knowledge Society (manuscript).

\section{Melléklet}

A fókuszcsoportos beszélgetések vezérfonala

\section{Bemutatkozás}

- bemutatkozás (csoportvezetô, asszisztens és minden résztvevố),

- tiszteletteljes tegezés, konstruktivitás,

- a kutatás hátterének és annak ismertetése, hogy az elhangzottak alapján tanulmány készül,

- engedélykérés hang- és képfelvétel készítéséhez,

- az interjú hossza egy-másfél óra,

- könyvajándékot kap minden résztvevő.

\section{A magyar információs társadalom fejlettsége}

- Milyen altémák tartoznak az információs társadalom területéhez?

- Melyek a legfontosabb, illetve legkritikusabb kérdések napjainkban a világban és itthon?

- Milyen Magyarország fejlettsége?

\section{Szereplốvilág}

Kik a kulcsszereplók ebben a térben, akik a legtöbbet tehetik az elóbbre jutásért? (Az azonosított szereplóket fel kell írni a táblára.) 


\section{Viszonyok a szereplók között}

- Az említett szereplók között milyenek a viszonyok (például hol vannak konfliktusok, szövetségek, kommunikációs zavarok stb.)? (A viszonyok ábrázolhatók a táblán.)

- Ki dominál, kik az elsődleges-meghatározó szereplók?

- Hol vannak egy képzeletbeli fontossági rangsorban a civilek?

- Milyen élólény lenne a civil szféra ebben a térben? Milyenek a többiek?

\section{A civilek és szerepük}

- Kik tekinthetốk civileknek?

- Mi lehet a civilek funkciója a magyar információs társadalomban?

- Melyek azok a civil szervezetek, amelyek a legtöbbet teszik a magyar információs társadalomért? (A tábla használatával.)

- Konkrét példák, esettanulmányok?

\section{A beszélgetések résztvevői}

\section{Állami szektor}

- Bárdos Ferenc (Nemzeti Civil Alap Tanács)

- Bódi Gábor (Elektronikus Kormányzati Központ - EKK)

- Ferge Sándor (Informatikai és Hírközlési Minisztérium - IHM)

- Király Edina (Országgyúlés Civil Irodája)

- Sebestény István (Központi Statisztikai Hivatal - KSH)

\section{Gazdasági szektor}

- Gróf Imre (Infopark Rt.)

- Lillin Ferenc (Vodafone)

- Loncsár Tibor (Vezető Informatikusok Szövetsége és MOL)

- Mlinarics József (Magyar Tartalomipari Szövetség - MATISZ)

- Molnár Imre (Hewlett Packard)

- Pallér Gábor (NOKIA)

- Pohly Ferenc (T-Com)

- Szkurka János (SUN Microsystems)

\section{Akadémiai szféra}

- Sükösd Miklós (Central European University - CEU, Védegylet)

- Porkoláb Anikó (Nonprofit Információs és Oktató Központ - NIOK)

- Nagy Ádám (Budapesti Múszaki Egyetem Információ- és Tudásmenedzsment Tanszék BME-ITM, Givil Szemle, INFONIA Alapítvány) 


\section{Civil szféra}

- Csapó Ida (Magyar Internetezố Nók Egyesülete - MINók)

- Nizák Péter (Soros Alapítvány)

- Alföldi István (Neumann János Számítógép-tudományi Társaság - NJSZT) 